\title{
Water Injection Effects On Performance Characteristics Of A Ci Engine
}

\author{
Sagar Patel ${ }^{1}$, Gaurav P Rathod ${ }^{2}$, Tushar M Patel ${ }^{3}$ \\ ${ }^{I}$ (ME Scholar, Department of Mechanical Engineering, KSV University, Gujarat, India) \\ ${ }^{2}$ (Assistant Professor, Department of Mechanical Engineering, KSV University, Gujarat, India) \\ ${ }^{3}$ (Associate Professor, Department of Mechanical Engineering, KSV University, Gujarat, India)
}

\begin{abstract}
A round all over world numbers of expérimentes are carried out to evaluate the effect of intake manifold water addition on the performance of diesel engines. An experimental study has been carried out to investigate the performance of diesel engine by injecting water in small quantities with the intake air. Single cylinder, four strokes, water cooled type diesel engine used in the experiments. Water flow rates equivalent to 9 , $16,38 \mathrm{ml} / \mathrm{min}$ supplied with intake air at 1 to $8 \mathrm{Kg}$ load. Obtained data were compared to performance data brake power, specific fuel consumption, mechanical efficiency obtained without a water supply to a diesel engine on the basis of performance.

Keywords: Water injection, Diesel, CI engine, SFC, NOx.
\end{abstract}

\section{Introduction}

Today's diesel engine is well established as determining power engine in the world of I.C engines. Substantial experiments are done to observe effects on brake power, indicated thermal efficiency, mechanical efficiency and specific fuel consumption. Higher fuel efficiency can be achieved by complete combustion of fuel, but the addition of water caused an incomplete combustion resulting decrease in brake thermal efficiency. Increase amount of water in emulsion also rises in brake thermal efficiency because the micro explosion of water in diesel gives addition torque on top of piston which increase expansion work, (D 20) emulsion shows highest thermal efficiency across all load engines [1]. Effect of direct water injection on diesel engine combustion. For $44 \%$ loads SFC decrease and for $86 \%$ load with increase in water decrease in SFC [2]. Real time water injection system. In RTWI system best performance was observed at $30 \%$ diesel fuel injection. The experiment worked that carried out on single cylinder engine established water injection system [3]. Different water quantities supplied constantly with air in the intake manifold of the engine. Data was recorded over a period of time.

\section{Experimental Setup And Technical Method}

Engine specifications are shown in table 1. The test engine used was a single cylinder, water cooled, direct injection stationary C. I engine. An electric dynamometer was used to provide engine load. Air box and burette were fitted to the intake manifold for measuring mass flow rate of air and water flow rate. A battery, starter and battery charge provides for engine, electric start arrangement. Lab view based engine performance analysis software package " Engine soft" is provided for study of engine performance like brake power, Indicated power, brake thermal efficiency, indicated thermal efficiency, specific fuel consumption and combustion analysis. Initial experiments were conducted using only diesel fuel with normal atmospheric air. All experiments were carried out at a compression ratio of 18 .

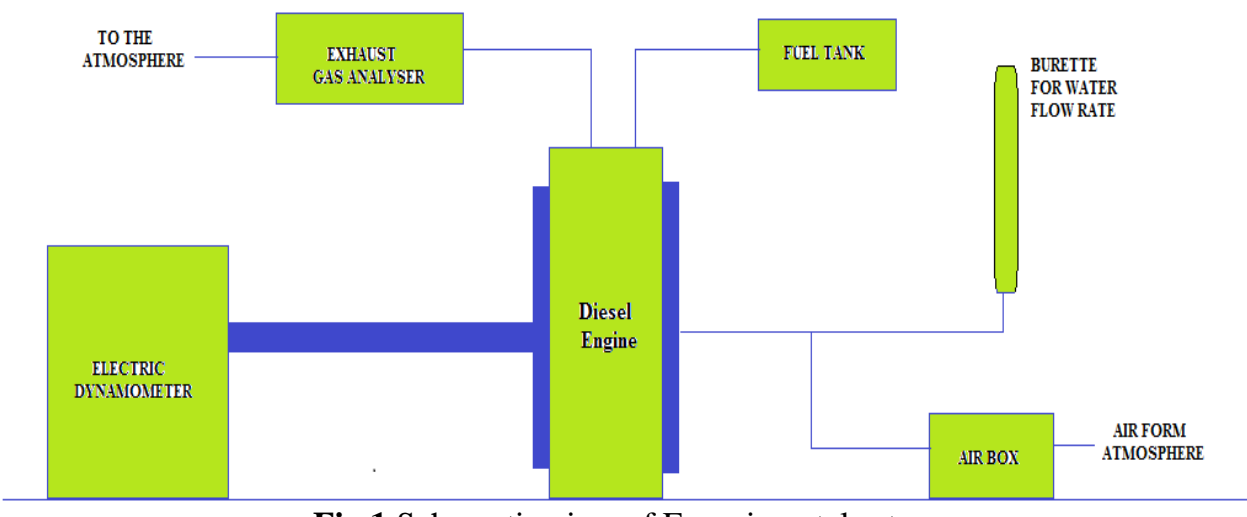

Fig.1 Schematic view of Experimental setup 


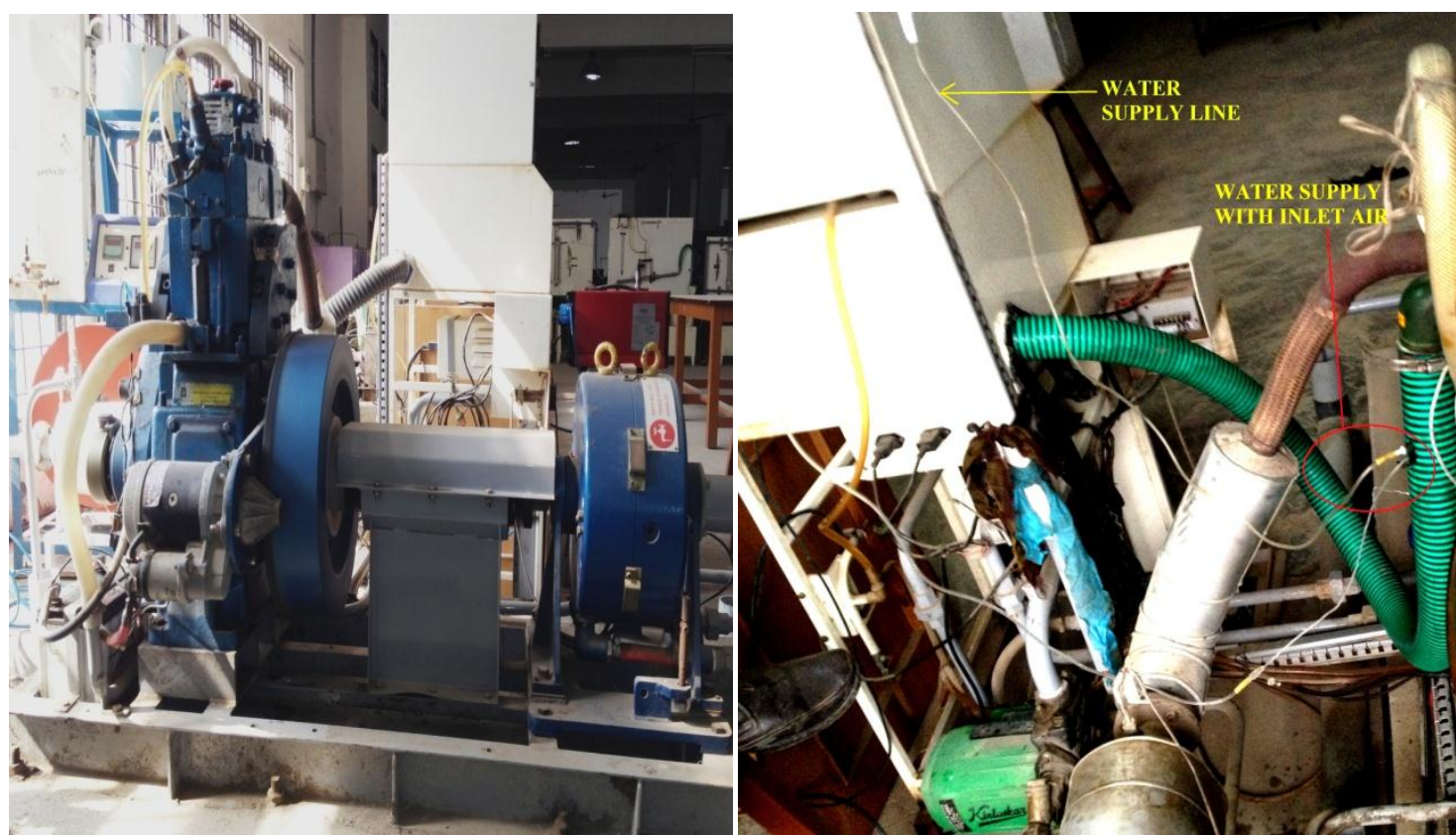

Fig.2 Lab View of the experimental setup

Engine specifications are shown in table 1. The test engine used was a single cylinder, water cooled, direct injection stationary C. I engine. An electric dynamometer was used to provide engine load. Air box and burette were fitted to the intake manifold for measuring mass flow rate of air and water flow rate. A battery, starter and battery charge provides for engine, electric start arrangement. Lab view based engine performance analysis software package " Engine soft" is provided for study of engine performance like brake power, Indicated power, brake thermal efficiency, indicated thermal efficiency, specific fuel consumption and combustion analysis. Initial experiments were conducted using only diesel fuel with normal atmospheric air. All experiments were carried out at a compression ratio of 18 .

\section{Technical Specifications}

\begin{tabular}{ll}
\hline Parameter & \multicolumn{1}{c}{ Details } \\
\hline Engine & $\begin{array}{l}\text { Single cylinder, research diesel } \\
\text { engine, water cooled }\end{array}$ \\
\hline Cooling & Water cooled \\
\hline Bore and stroke & $87.50 \mathrm{~mm}$ and $110.00 \mathrm{~mm}$ \\
\hline Compression ratio & $18: 1$ \\
\hline Rated speed & 1500 r.p.m \\
\hline Swept volume & $661.45 \quad$ CC \\
\hline
\end{tabular}

III. Result And Discussion

\begin{tabular}{|c|c|c|c|c|c|c|c|c|c|c|c|c|}
\hline & \multicolumn{3}{|c|}{ Diesel } & \multicolumn{3}{|c|}{$9 \mathrm{ml} / \mathrm{min}$} & \multicolumn{3}{|c|}{$16 \mathrm{ml} / \mathrm{min}$} & \multicolumn{3}{|c|}{$38 \mathrm{ml} / \mathrm{min}$} \\
\hline $\begin{array}{c}\text { Loa } \\
\text { d } \\
(\mathbf{K g} \\
)\end{array}$ & $\begin{array}{c}\text { SFC } \\
\text { (Kg/kwh } \\
)\end{array}$ & $\begin{array}{c}\text { B.T. } \\
\mathbf{E} \\
(\%)\end{array}$ & $\begin{array}{c}\text { Mec } \\
\text { h.Eff } \\
\text { i. } \\
(\%)\end{array}$ & $\begin{array}{c}\text { SFC } \\
(\mathrm{Kg} / \mathrm{kwh})\end{array}$ & $\begin{array}{c}\text { B.T.E } \\
(\%)\end{array}$ & $\begin{array}{l}\text { Mech. } \\
\text { Effi. } \\
(\%)\end{array}$ & $\begin{array}{c}\text { SFC } \\
(\mathrm{Kg} / \mathrm{kwh} \\
)\end{array}$ & $\begin{array}{c}\text { B.T. } \\
\mathbf{E} \\
(\%)\end{array}$ & $\begin{array}{c}\text { Mech. } \\
\text { Effi. } \\
(\%)\end{array}$ & $\begin{array}{c}\mathrm{SFC} \\
(\mathrm{Kg} / \mathrm{kwh} \\
)\end{array}$ & $\begin{array}{c}\text { B.T.E } \\
(\%)\end{array}$ & $\begin{array}{c}\text { Mech. } \\
\text { Effi. } \\
(\%)\end{array}$ \\
\hline 1 & 1.14 & 6.15 & 9.95 & 1.36 & 6.77 & 9.96 & 1.55 & 5.73 & 8.61 & 1.6 & 6.34 & 10.33 \\
\hline 2 & 0.73 & 12.18 & 17.73 & 0.77 & 11.38 & 18.09 & 0.79 & 12.97 & 17.81 & 0.81 & 10.45 & 17.3 \\
\hline 3 & 0.54 & 15.71 & 23.88 & 0.58 & 14.55 & 23.53 & 0.62 & 13.97 & 22.62 & 0.63 & 13.65 & 25.34 \\
\hline 4 & 0.43 & 20.01 & 30.5 & 0.48 & 17.67 & 29.06 & 0.5 & 19.17 & 28.74 & 0.51 & 17.8 & 29.07 \\
\hline 5 & 0.37 & 22.86 & 36.15 & 0.42 & 20.06 & 33.44 & 0.44 & 21.34 & 33.28 & 0.45 & 21.54 & 34.65 \\
\hline 6 & 0.35 & 23.99 & 39.58 & 0.37 & 21.17 & 38.15 & 0.4 & 22.88 & 36.41 & 0.41 & 24.49 & 38.01 \\
\hline 7 & 0.32 & 26.08 & 44.64 & 0.34 & 25.27 & 41.2 & 0.35 & 25.47 & 41.59 & 0.36 & 26.12 & 41.21 \\
\hline 8 & 0.31 & 27.65 & 47.48 & 0.33 & 25.34 & 44.53 & 0.34 & 25.49 & 45.55 & 0.35 & 27.7 & 44.77 \\
\hline
\end{tabular}




\section{Specific Fuel consumption}

Fig-2, it shows that specific fuel consumption increase with increased load. By increasing water flow rate $9 \mathrm{ml} / \mathrm{min}, 16 \mathrm{ml} / \mathrm{min}, 38 \mathrm{ml} / \mathrm{min}$ specific fuel consumption increase for at load condition. Concentration of water increase specific fuel consumption. But from fig- 2 it shows that SFC is the best in $9 \mathrm{ml} / \mathrm{min}$ which is almost near to diesel with normal air supply.

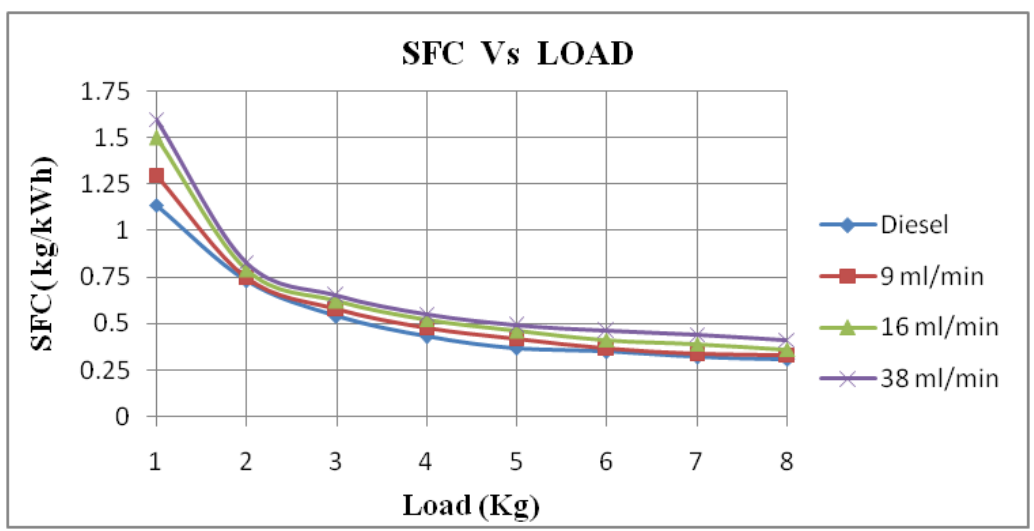

Fig.3 Variation of specific fuel consumption with load

\section{Brake thermal efficiency}

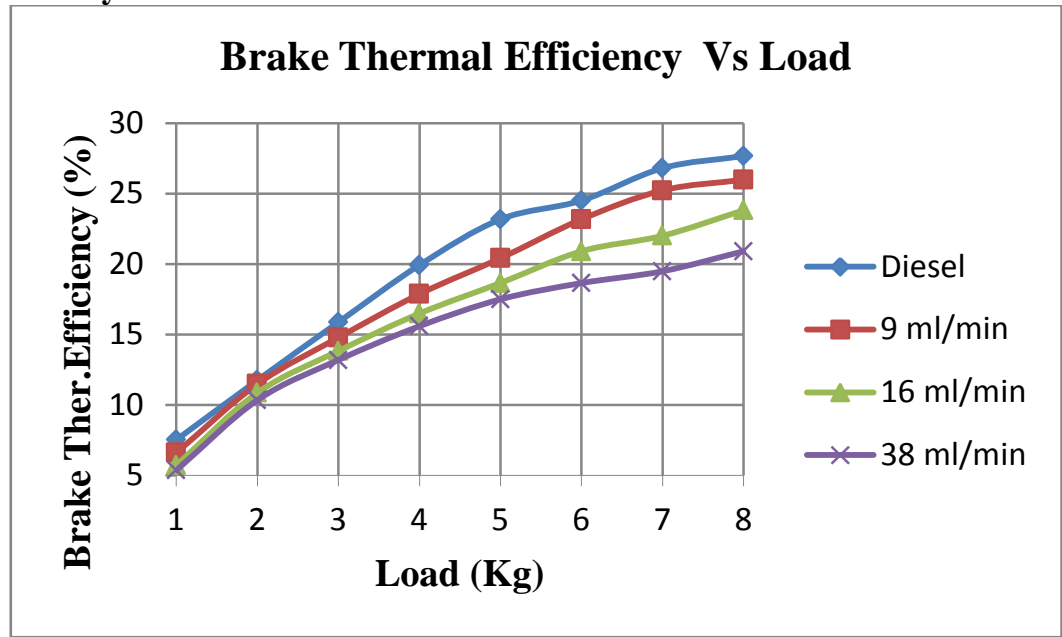

Fig 3. Shows variation of brake thermal efficiency with load

Brake thermal efficiency is a rate of brake power to the calorific value of the fuel. Fig-3 shows brake thermal efficiency decreased with increased load. As water flow rates increase brake thermal efficiency decreased. Brake thermal efficiency is minimum at $38 \mathrm{ml} / \mathrm{min}$ water flow rate. At the $38 \mathrm{ml} / \mathrm{min}$ water flow rate gives lower brake thermal efficiency compare to $9 \mathrm{ml} / \mathrm{min}$ and $16 \mathrm{ml} / \mathrm{min}$.

\section{Mechanical efficiency}

Mechanical efficiency is a rate of brake power to indicate the power of the engine. From fig-5 it is clear that mechanical efficiency is high at $38 \mathrm{ml} / \mathrm{min}$ compare to $9 \mathrm{ml} / \mathrm{min}$ and $16 \mathrm{ml} / \mathrm{min}$ water supply. From the graph it is concluded that mechanical efficiency at $38 \mathrm{ml} / \mathrm{min}$ give better result at high load $(8 \mathrm{~kg}) \mathrm{but}$ at a lower rate of water supply mechanical efficiency is more decrease. 


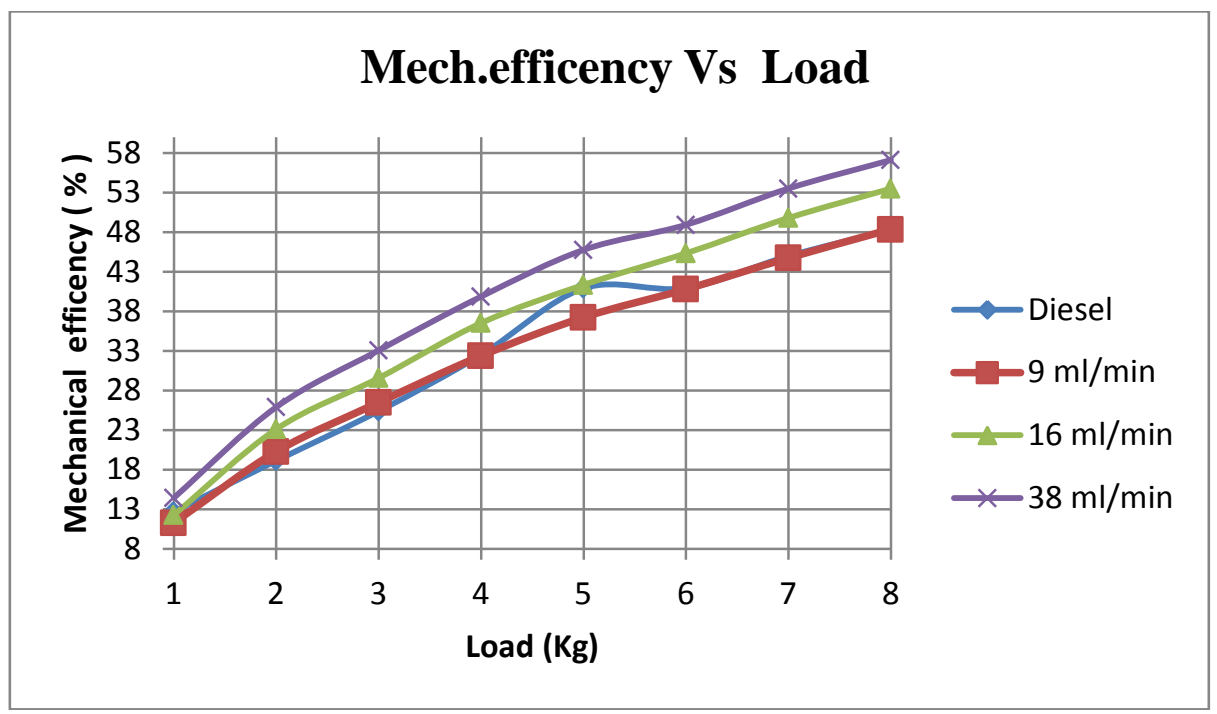

Fig.4 shows the variation of brake thermal efficiency with load

$\mathrm{NO}_{\mathrm{x}}$

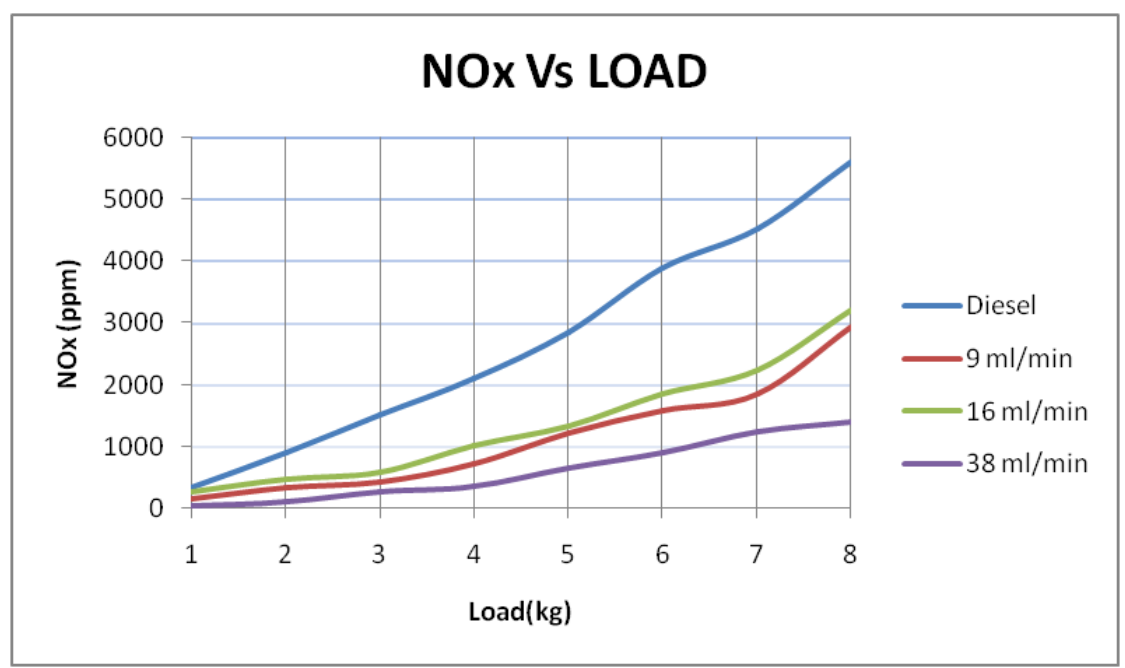

Fig.5 variation of $\mathrm{NO}_{\mathrm{X}}$ level with load

The comparison of $\mathrm{NO}_{\mathrm{X}}$ formation in cylinder at 1 to $8 \mathrm{~kg}$ load conditions for different water flow rates $9 \mathrm{ml} / \mathrm{min}, 16 \mathrm{ml} / \mathrm{min}$ and $38 \mathrm{ml} / \mathrm{min}$, tested is given in fig-5. As can be seen from the fig water injected caused to decrease $\mathrm{NO}_{\mathrm{X}}$ emissions. The $\mathrm{NO}_{\mathrm{X}}$ emission decreases at all engine loads with increase in water flow rate. The minimum $\mathrm{NO}_{\mathrm{X}}$ is $45 \mathrm{ppm}$ at $1 \mathrm{~kg}$ load with $38 \mathrm{ml} / \mathrm{min}$

It is clear from the above result that water in the form of a fine spray droplets exerts positive effects on exhaust emission particular to $\mathrm{NO}_{\mathrm{x}}$. The combined effect of absorbing heat developed by fuel during combustion and increased partial pressure of oxygen puts down the combustion temperature and thus it help to decrease formation of $\mathrm{NO}_{\mathrm{X}}$. As can be seen from above fig increase water flow rate give a more $\mathrm{NO}_{\mathrm{X}}$ reduction at all load conditions.

\section{Conclusion}

In this study the effects of manually controlled water injection system for emission have been established. There is a significant decrease in performance at higher water flow rates, it also gives better reduction result of $\mathrm{CO}, \mathrm{CO}_{2}, \mathrm{HC}$ at all engine loads. Based on the experimental results the main effects of water injection are summarized as follows:

1) From above comparison, it concluded that $9 \mathrm{ml} / \mathrm{min}$ found best over entire different flow rates. It shows from experiments water contains in combustion chamber carry heat developed during the expansion stroke and lowering brake thermal efficiency. 
2) Mechanical efficiency was almost increasing with increase in flow rate compared to normal air supply. It is concluded that higher water flow rate supply can be used in diesel engines without any modify the design of the intake manifold of diesel engines.

3) A higher quantity of water required during experiments, it was main challenge when this water injection system implemented in vehicles. It can be solved by reuse of water that used to cool the radiator. In place of water, steam can also be injected with inlet air and better results were obtained.

4) In spite of decrease in performance, highly reductions in emission parameters like $\mathrm{NO}_{\mathrm{x}}$. So that favored the use of water injection system in heavy commercial vehicles.

\section{References}

[1] $\mathrm{NO}_{\mathrm{X}}$ and $\mathrm{HC}$ emission control using water emulsified diesel in single cylinder diesel engine. Asian research publishing network. Vol. 4, No. 8, ISSN 1819-6608. 2009

[2] Effect of direct water injection on DI diesel engine combustion. Society of automotive engineers. 200001-2938. 2000.

[3] Effect of diesel and water co-injection with real-time control on diesel engine performance and emissions. Society of automotive engineers technical paper series.2008-01-1190. 2008.

[4] Performance characterization of single cylinder diesel engine fuelled with sesame oil - diesel and its blend with ethanol. International Journal of Engineering Research \& Technology. ISSN: 2278-0181. 2012.

[5] Performance analysis of single cylinder diesel engine fuelled with Pyrolysis oil - diesel and its blend with ethanol. International Journal of Engineering Research \& Technology. ISSN: 2278-0181. 2012.

[6] Theoretical and experimental investigation of diesel engine with steam injection system on performance and emission parameters. Applied Thermal Engineering. 54 (2013) 161-170. 2013. 